\title{
Çok ilaca Dirençli İnvaziv Acinetobacter baumannii İzolatlarında Biyofilm ve Biyofilm iliş̧kili Virülans Genlerinin Varlığı
}

\section{Existence of Biofilm and Biofilm-Associated Virulence Genes in Multi-Drug Resistant Invasive Acinetobacter baumannii Isolates}

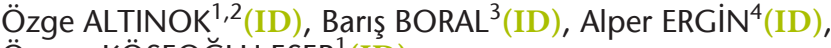 \\ Özgen KÖSEOĞLU'ESER ${ }^{1}($ ID) \\ ${ }^{1}$ Hacettepe Üniversitesi Tıp Fakültesi, Tıbbi Mikrobiyoloji Anabilim Dalı, Ankara. \\ ${ }^{1}$ Hacettepe University Faculty of Medicine, Department of Medical Microbiology, Ankara, Turkey. \\ 2 istanbul Aydın Üniversitesi Tıp Fakültesi, Tıbbi Mikrobiyoloji Anabilim Dalı, İstanbul. \\ ${ }^{2}$ Istanbul Aydin University Faculty of Medicine, Department of Medical Microbiology, Istanbul, Turkey. \\ ${ }^{3}$ Adana Şehir Hastanesi, İmmünoloji Bölümü, Adana. \\ 3 Adana City Hospital, Department of Immunology, Adana, Turkey. \\ ${ }^{4}$ Hacettepe Üniversitesi Sağlık Hizmetleri Meslek Yüksekokulu, Tıbbi Laboratuvar Programı, Ankara. \\ ${ }^{4}$ Hacettepe University School of Health Services, Medical Laboratory Programme, Ankara, Turkey.
}

* Bu çalış̧ma, Hacettepe Üniversitesi Bilimsel Araştırmalar Birimi tarafından desteklenmiştir (Proje no: THD-2015-7672).

** Bu çalışma, birinci yazarın Hacettepe Üniversitesi Sağılk Bilimleri Enstitüsü Mikrobiyoloji Programı Yüksek Lisans tez çalışmasıdır.

Makale Atıfı: Altınok Ö, Boral B, Ergin A, Köseoğlu Eser Ö. Çok ilaca dirençli invaziv Acinetobacter baumannii izolatlarında biyofilm ve biyofilm ilişkili virülans genlerinin varlığı. Mikrobiyol Bul 2020;54(1):40-49.

\section{Öz}

Acinetobacter baumannii, hastane kaynaklı enfeksiyonlara yol açan çok ilaca dirençli (ÇiD) gramnegatif bir patojendir. A.baumannii'ye bağlı gelişen hastane kaynaklı enfeksiyonlar özellikle yoğun bakım ünitelerinde yatan hastalarda ortaya çıkmaktadır. Bu etkene bağlı önemli enfeksiyonlar pnömoni, bakteriyemi, endokardit, deri ve yumuşak doku, idrar yolu enfeksiyonları ve menenjittir. İnsanlara bulaş genellikle hastane ortamı veya sağlık personeli aracııı̆ıyla olmaktadır. A.baumannii'de virülans, bakterinin antibiyotiklere çoklu direnç göstermesinin yanı sıra biyofilm oluşturma yeteneğiyle de artış göstermektedir. A.baumannii izolatlarının biyofilm oluşturmasında farklı proteinleri kodlayan genlerin [kıvrık lif proteini "curli fiber" geni ( $\operatorname{csg} A)$, "chaperon-usher" fimbriya geni (csuE) ve dış membran protein geni (ompA)] önem taşıdığı düşünülmektedir. Bu çalışmada, ÇiD invaziv A.baumannii izolatlarında biyofilm yapımı ve virülans genlerinin gösterilmesi amaçlanmıştır. Çalışmaya, ÇiD oldukları ve benzerlik durumları PFGE yöntemiyle daha önceden belirlenmiş invaziv A.baumannii izolatları $(n=156)$ dahil edilmiştir. Biyofilm yapımı, kantitatif mikroplak biyofilm yöntemiyle belirlenmiştir. Virülans genleri olan csgA, csuE, fimH, ompA ve bla $a_{\text {PER-1 }}$ varlığı polimeraz zincir reaksiyonu (PCR) ile araştırılmıştır. Tüm izolatların \%60.3 (94/156)'ünün biyofilm oluşturduğu saptanmıştır. Bu 94 izolatın 17'si zayıf, 33'ü orta, 44'ü kuvvetli biyofilm oluşturma yeteneğinde bulunmuştur. İzolatların ortalama biyokütle oluşturma kapasitesinin 2.23 \pm 0.0033 olduğu belirlenmiştir. Çalışmaya dahil edilen izolatlar arasında $(n=156) \operatorname{csg} A, \operatorname{csuE}$, ompA, fimH 
ve $b l a_{\text {PER-1 }}$ genleri sırasıyla \%71.2, \%32.1, \%21.8, \%7.1 ve \%3.2'sinde saptanmıştır. Biyofilm yapımı gösteren izolatlar arasında csgA, ompA, csuE, fimH virülans genlerinin sıklığı ise sırasıyla; \%41.5, \%24.5, \%20.2 ve \%5.3 olarak tespit edilmiştir. Biyofilm oluşturan izolatların PFGE pulsotiplerine göre en sık olarak pulsotip II \%19.1 (18/94), pulsotip IX \%17.0 (16/94) ve pulsotip VI \%12.8 (12/94) içerisinde yer aldıkları saptanmışıı. Bu çalışmada, zayıf, orta ve güçlü biyofilm yapan izolatlarda virülans genlerinin dağılımı karşılaştııılığında, çalışılan bütün genlerin güç̧ı̈ ve orta pozitif biyofilm varlığı olan izolatlarda daha fazla sayıda olduğu saptanmıştır. Bu durum, sırasıyla csgA, csuE ve ompA gen varlıklarının izolatlardaki biyofilm oluşumunda katkılarının olduğunu, fimH geninin ise biyofilm yapımıyla ilişkili olmadığını göstermiştir.

Anahtar kelimeler: Acinetobacter baumannii; biyofilm; virülans genleri; polimeraz zincir reaksiyonu.

\section{ABSTRACT}

Acinetobacter baumannii is a multi-drug resistant (MDR) gram-negative pathogen leading to nosocomial infections. Hospital-acquired infections due to A.baumannii occur especially in patients hospitalized in intensive care units. Important infections related to this bacterium are pneumonia, bacteremia, endocarditis, skin and soft tissue, urinary tract infections and meningitis. Human transmission is usually through the hospital environment or through medical personnel. A.baumannii isolates increases their virulence not only being multiple resistance to antibiotics but as well as the ability to form biofilm. The biofilm formation of A.baumannii isolates were mostly related with genes encoding curli fiber $(\operatorname{csg} A)$, the chaperone-usher fimbria (csuE) and the outer membrane (ompA). The aim of this study was to demonstrate biofilm production and virulence genes in MDR invasive A.baumannii isolates. MDR and similarity status previously known invasive A.baumannii $(n=156)$ isolates were included in the study. Biofilm production was determined by quantitative microplate biofilm method. Virulence genes $\operatorname{csg} A$, csuE, fimH, ompA and bla $a_{\text {PER-1 }}$ were investigated by polymerase chain reaction (PCR). It was determined that $60.3 \%(94 / 156)$ of all the isolates formed biofilm. Of these 94 isolates, 17 were weak, 33 were medium and 44 were strong. The mean biomass forming capacity of the isolates was found to be 2.23 \pm 0.0033 . Among the isolates included in the study $(n=156)$ the frequency of $\operatorname{csg} A$, csuE, ompA, fimH and $b l a_{\text {PER-1 }}$ genes were $71.2 \%, 32.1 \%, 21.8 \%, 7.1 \%$ and $3.2 \%$ respectively. The frequency of $\operatorname{csg} A$, ompA, bap, csuE, fimH virulence genes were found to be $41.5 \%, 24.5 \%, 20.2 \%$ and $5.3 \%$ among biofilm positive isolates respectively. Biofilm-forming isolates were most commonly found in pulsotype II $19.1 \%$ (18/94), pulsotype IX 17.0\% (16/94) and pulsotype VI 12.8\% (12/94). In this study, when the distribution of virulence genes were compared with the isolates that have weak, medium and strong biofilm, all of the studied genes were found to be more abundant in isolates with strong and medium positive biofilm production. This has shown that excluding $i m H$ gene, $\operatorname{csg} A, \operatorname{csu} E$ and ompA genes have contributed to the biofilm formation in invasive A.baumannii isolates, respectively.

Keywords: Acinetobacter baumannii; biofilm; virulence genes; polymerase chain reaction.

\section{Giriş̧}

Acinetobacter baumannii, çok ilaca dirençli (ÇiD) olması nedeniyle yoğun bakım ünitelerinde yatan hastalarda tedavide önemli sorunlara yol açan ve sık izole edilen patojenler arasında yer almaktadır. A.baumannii, pnömoni, bakteriyemi, endokardit, deri ve yumuşak doku, idrar yolu ve menenjit gibi enfeksiyonlara yol açmaktadır. Insanlara bulaş genellikle hastane ortamı veya sağlık personeli aracılığıyla olmaktadır ${ }^{1-3}$.

Hastane kaynaklı pnömoni A.baumannii enfeksiyonlarının en önemli klinik tablosudur. Enfeksiyon, sıklıkla mekanik ventilasyon uygulanan yoğun bakım hastalarında ortaya çıkmaktadır. Yoğun bakım hastalarında sık görülen başka bir enfeksiyon ise, A.baumannii'ye bağlı kan dolaşımı enfeksiyonlarıdır. Bu enfeksiyonların gelişmesinde rol oynayan risk 
faktörleri arasında; immünsupresyon, solunum yetmezliğine bağlı ventilatör kullanımı, uzun süreli antibiyotik kullanımı, A.baumannii ile kolonizasyon ve invaziv girişimler bulunmaktadır ${ }^{2-5}$.

A.baumannii'ye bağlı enfeksiyonların artışı ile ortaya çıkan klinik önemine rağmen, bakterinin patogenezinde rol oynayan faktörler hakkında çok az bilgi bulunmaktadır ${ }^{5}$. A.baumannii hastane ortamında bulunan yüzeylerde, tıbbi cihazlar üzerinde uzun süre canlı kalabilme potansiyeline sahiptir. A.baumannii'nin özellikle kateter ve solunum cihazlarına kontaminasyonu sonucu hastane ortamında uzun süre hayatta kalabilme yeteneği göstermesi biyofilm yapımına ve çoklu ilaç direncine bağlıdır ${ }^{3}$.

A.baumannii'nin cansız yüzeylerde biyofilm oluşturması ile antibiyotiklere dirençli fenotiplerde biyofilm ilişkili genlerin sıklığı arasındaki bağlantı yapılan çalışmalarla gösterilmiştir. A.baumannii ATCC 19606 suşunda pilus yapımına neden olan CsuA/BABCDE operonunun yüzeye tutunma ve biyofilm yapımı için gerekli olduğu gösterilmiştir. Başka bir operon olan poli N-asetil glukozamin (pgaABC)'in de biyofilm yapımında rolü olduğu saptanmıştır ${ }^{6}$. A.baumannii'nin canlı yüzeylere tutunması ve biyofilm oluşturmasıyla ilgili bilgiler sınırlı sayıdadır. Bakteri, insan epitel hücrelerine ve Candida albicans filamentlerine dış membran protein A (ompA)'nın yardımıyla tutunmaktadır ${ }^{7}$.

A.baumannii'nin yüzeye tutunma ve biyofilm oluşturma mekanizması çok geniş hücresel ve çevresel etkenlere bağlıdır. Biyofilm ile ilişkili protein (bap), dış zar proteini A (ompA), bla $a_{\text {PER-1 }}, C s U A / B A B C D E$ chaperone-usher pili montaj sistemi ve demir alma mekanizmalarının, A.baumannii izolatlarında biyofilm oluşumu ile bağlantılı olduğu ve ayrıca ompA ve bla $a_{\mathrm{PER}-1}$ 'in bakterilerin epitelyal hücrelere ve abiyotik yüzeylere bağlanmasından da sorumlu olduğu gösterilmiştir ${ }^{3}$.

Bu çalışmada, ÇiD invaziv A.baumannii izolatlarında biyofilm yapımının ortaya konulması, bakterinin virülans genleri ile biyofilm yapımı arasındaki ilişkinin gösterilmesi ve antibiyotiklere direnç gelişimi ile biyofilm yapımı arasındaki ilişkinin ortaya çıkarılması amaçlanmıştır.

\section{GEREÇ ve YÖNTEM}

\section{Bakteri İzolatları}

Bu çalışmaya, Türkiye'nin farklı coğrafik bölgelerinde yer alan toplam 10 merkezden elde edilen ÇID oldukları ve benzerlik durumları PFGE yöntemiyle daha önceden belirlenmiş invaziv A.baumannii izolatları $(n=156)$ dahil edildi ${ }^{8}$. Bu izolatlar kan, beyin omurilik sıvısı (BOS) ve özellikle cerrahi yoğun bakım ünitelerinde enfeksiyon tanısı ile tedavi edilen hastaların invaziv örneklerinden elde edildi. Çalışmaya dahil edilen izolatlar daha önce konvansiyonel yöntemlerle tanımlanmış ve bla ${ }_{\text {OXA-51 }}$ gen varlığı yönünden incelenerek tür düzeyinde tanımlamaları doğrulanmıştır. İzolatların antibiyotik duyarlııkları daha önce "Clinical and Laboratory Standards Institute (CLSI)" rehberinin önerileri doğrultusunda mikrodilüsyon ve antibiyotik gradiyent test yöntemleriyle belirlenmiştir. 


\section{Biyofilm Oluşumunun Kantitatif Olarak Belirlenmesi}

Biyofilm oluşumunu değerlendirmek amacıyla Badave ve Dhananjay tarafından geliştirilen mikroplak yöntemi kullanıldı' ${ }^{9}$ Bu amaçla; $180 \mu$ l triptik soy buyyon (TSB), steril 96 kuyucuklu polistiren mikroplaklara dağıtıldı. Üzerlerine $0.5 \mathrm{McFarland} \mathrm{bulanıklığında} \mathrm{hazır-}$ lanmış bakteri süspansiyonundan $20 \mu$ lilave edildi ve $18-20$ saat $35^{\circ} \mathrm{C}^{\prime}$ de inkübe edildi. Kuyucuklar, 24 saatlik inkübasyon sonunda $200 \mu$ fosfat tampon çözeltisi (PBS) eklenerek üç kez yıkandı, takiben plaklar ters çevrilerek kurutuldu. Kuruyan plaklardaki kuyucuklara 200 $\mu$ metanol ilave edildi. Metanol, plaklar oda sıcaklığında 15 dakika bekletilerek uzaklaştırıldı. Kuyucuklara $20 \mu \mathrm{l} \% 1$ kristal viyole eklenerek 15 dakika boyandı. Kuyucuklar, musluk suyunda durulandı ve 15 dakika oda sıcaklığında kurutuldu. Son olarak, kuyucuklara 100 ul \%95'lik etanol ilave edildi. Mikroplaklar spektrofotometrede 15 dakika içinde okutularak 620 nm'de optik dansite (OD) belirlendi. Her deney üç kez tekrarlandı ve ortalama OD tespit edildi. A.baumannii ATCC 19606 suşu pozitif kontrol olarak kullanıldı. Biyofilm oluşumu aşağıdaki formüle göre zayıf, orta ve güçlü olarak sınıflandııldı. Biyofilm oluşumu negatif; OD (izolat) $\leq$ OD (negatif kontrol), zayıf biyofilm oluşumu; OD (negatif kontrol) < OD (izolat) < 2 x OD (negatif kontrol), orta biyofilm oluşumu; $2 \times$ OD (negatif kontrol) < OD (izolat) < 4 x OD (negatif kontrol) ve güçlü biyofilm oluşumu; OD (izolat) $>4 \times$ OD (negatif kontrol) olarak kabul edildi.

\section{Virülans Genlerinin Polimeraz Zincir Reaksiyonu ile Belirlenmesi}

DNA ekstraksiyonu kaynatma yöntemiyle yapıldı. Kanlı agara tek koloni ekim yöntemiyle ekilen bakterilerin 18-24 saatlik inkübasyonu sonunda, bakteri kültüründen tek koloni alındı. Mueller Hinton Buyyonda inkübe edilen bakteri ardından, 15 dakika 3000 xg'de santrifüj edildi. Üstte kalan sıvı döküldü. Çökelti üzerine $1 \mathrm{ml}$ Tris/EDTA (TE) çözeltisi eklenerek vortekslendi ve mikrosantrifüj tüplerine aktarıldı. Yıkama işlemi üç kez tekrarlandı. En son yıkamadan sonra çökelti üzerine $100 \mu \mathrm{l}$ TE tamponu eklendi ve tüpler ısı bloğuna konarak 15 dakika $100^{\circ} \mathrm{C}^{\prime}$ de bekletildi. Mikrosantrifüjde $12.000 \mathrm{rpm}$ 'de bir dakika santrifüj edildi. Üst sıvı, çökeltiye dokunmadan yeni bir steril mikrosantrifüj tüpüne alındı ve elde edilen DNA moleküler testlerin uygulanması aşamasına kadar $-20^{\circ} \mathrm{C}$ 'de saklandı.

Patojenite genlerinin varlığının araştırılmasında, virülans genlerine ait primerler kullanılarak PCR amplifikasyonu yapıldı. Çalışmada kullanılan primer dizileri Tablo I'de gösterilmiştir. PCR karışımı $25 \mu$ l hacimde; Taq DNA tamponu, $2.5 \mathrm{mM} \mathrm{MgCl}{ }_{2}, 200 \mu \mathrm{M}$ dNTP karışım, 30 pmol (her biri) primer ve $1 \mathrm{U}$ Taq polimeraz $2 \mu$ I DNA olacak şekilde hazırlandı. DNA amplifikasyonu ısı döngü cihazı (Global Genomics Partner, MyGenie96, ABD) ile gerçekleştirildi. Amplifikasyon, ilk denatürasyon $94^{\circ} \mathrm{C}^{\prime}$ de 10 dakika gerçekleştirildikten sonra; 35 döngü denatürasyon $94^{\circ} \mathrm{C}^{\prime}$ de 30 saniye, primer birleşmesi bla ${ }_{\mathrm{Omp}-\mathrm{A}}$ için $52^{\circ} \mathrm{C}^{\prime} \mathrm{de}$, bla $a_{\mathrm{csuE}}$ için $63^{\circ} \mathrm{C}^{\prime}$ de, bla $a_{\text {csgAm }}$ için $48^{\circ} \mathrm{C}^{\prime}$ de, bla $a_{\text {FimH }}$ için $48^{\circ} \mathrm{C}^{\prime}$ de 30 saniye ve $72^{\circ} \mathrm{C}^{\prime}$ de 1 dakika olacak şekilde uygulandı. Amplifikasyonun sonunda $72^{\circ} \mathrm{C}^{\prime}$ de 10 dakika son uzamanın ardından reaksiyon sonlandırıldı. PCR ürünleri $\% 2^{\prime}$ lik agaroz jel elektroforezinde yürütüldü. Moleküler ağırlık belirteci olarak 100 bp DNA ladder kullanıldı. 


\begin{tabular}{|c|c|c|c|}
\hline Gen & Primer dizisi & Baz çifti (bp) & Kaynak \\
\hline \multirow[t]{2}{*}{$\operatorname{csg} A$} & F-5'-ACT CTG АCT TGA CTA TTA CC-3' & 200 & 10 \\
\hline & R-5'-AGA TGC AGT CTG GTC AAC-3' & & \\
\hline \multirow[t]{2}{*}{$\operatorname{csu}$} & F-5'-ATG CAT GTT CTC TGG ACT GAT GTT GAC-3' & 976 & 11 \\
\hline & R-5'-CGA CTT GTA CCG TGA CCG TAT CTT GAT AAG-3' & & \\
\hline \multirow[t]{2}{*}{$\mathrm{fimH}$} & F-5'-TGC AGA ACG GAT AAG CCG TGG-3' & 508 & 12 \\
\hline & R-5'-GCA GTC ACC TGC CCT CCG GTA-3' & & \\
\hline \multirow[t]{2}{*}{ ompA } & F-5'-CAA TTG TTA TCT CTG GAC-3' & 966 & 13 \\
\hline & R-5'-ACC TTG AGT AGA CAA ACG A-3' & & \\
\hline \multirow[t]{2}{*}{$b / a_{\text {PER-1 }}$} & F-5'-ATG AAT GTC ATT ATA AAA GC-3' & 925 & 14 \\
\hline & R-5'-AAT TTG GGC TTA GGG CAG AA-3' & & \\
\hline
\end{tabular}

\section{BULGULAR}

Tüm izolatların \%60.3 (94/156)'ünün biyofilm oluşturduğu saptanmıştır. Biyofilm oluşturan 94 izolatın 17'sinin zayıf, 33'ünün orta, 44'ünün güçlü biyofilm oluşturma yeteneğinde olduğu bulunmuştur. A.baumannii izolatlarında biyofilm yapım düzeyine göre dağılım Tablo II'de gösterilmiştir.

Yapılan test işlemleri sırasında elde edilen negatif/pozitif kontrollerin ve izolatların üç kez okuma sonrası elde edilen OD sonuçlarının ortalamalarına göre, ortalama biyofilm biyokütle oluşturma kapasitesinin $2.23 \pm 0.0033$ olduğu belirlenmiştir (Şekil 1).

Çalışmaya dahil edilen izolatlar arasında $(\mathrm{n}=156) \operatorname{csg} A, \operatorname{cs} U E$, ompA, fimH ve bla PER-1 $_{\text {gen- }}$ leri sırasıyla \%71.2 $(n=111), \% 32.1(n=50), \% 21.8(n=34), \% 7.1(n=11)$ ve \%3.2 $(n=$ 5)'sinde saptanmıştır.

Biyofilm varlığı saptanan 94 izolatın 79 (\%84.0)'unda virülans geni varlığı saptanmıştır. Biyofilm yapımı gösteren izolatlar arasında $\operatorname{csg} A, o m p A, \operatorname{csuE}$, fimH virülans genlerinin sıklığı ise sırasılyla; \%41.5 ( $n=39), \% 24.5(n=23), \% 20.2(n=19)$ ve \%5.3 ( $n=5)$ olarak tespit edilmiştir. A.baumannii izolatlarındaki virülans genleri ile biyofilm yapım düzeyi arasındaki ilişki Tablo III'te gösterilmiştir.

\begin{tabular}{lc}
\hline Tablo II. Acinetobacter baumannii İzolatlarında Biyofilm Yapım Düzeyine Göre Dağıım \\
\hline Biyofilm yapım düzeyi & Sayı \\
\hline Güçlü pozitif & 44 \\
Orta pozitif & 33 \\
Zayıf pozitif & 17 \\
Negatif & 62 \\
Toplam & 156 \\
\hline
\end{tabular}




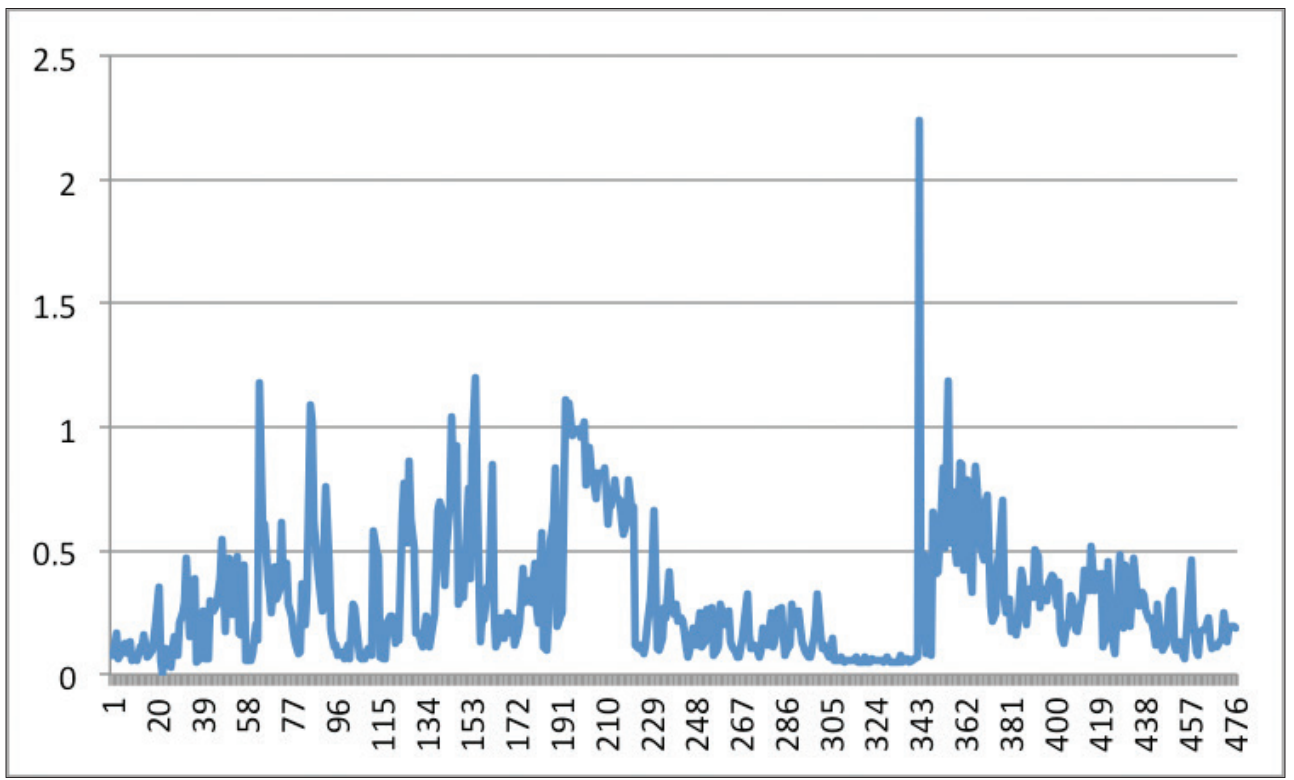

Şekil 1. OD620'de biyofilm biyokütle dağılımı (2.23 \pm 0.0033).

Tablo III. Acinetobacter baumannii Izolatlarındaki Virülans Genleri ile Biyofilm Yapım Düzeyi Arasındaki ilişki

\begin{tabular}{lcccc}
\hline Gen tipi & Biyofilm güçlü (+) & Biyofilm orta (+) & Biyofilm zayıf (+) & Toplam (n) \\
\hline $\operatorname{csg} A$ & 16 & 15 & 8 & 39 \\
ompA & 8 & 5 & 10 & 23 \\
$\operatorname{csuE}$ & 14 & 4 & 1 & 19 \\
$\mathrm{fimH}$ & 3 & 2 & - & 5 \\
\hline
\end{tabular}

A.baumannii izolatlarının elde edildiği on farklı merkeze göre değerlendirme yapıldığında, biyofilm oluşumu gözlenen izolatların \%22.3 (21/94)'ünün tek bir merkezden olduğu belirlenmiştir. Biyofilm oluşturan izolatların PFGE pulsotiplerine göre en sık pulsotip II \%19.1 (18/94), pulsotip IX \%17.0 (16/94) ve pulsotip VI \%12.8 (12/94)'de yer aldığı saptanmışır. Pulsotip II içinde güçlü biyofilm üreten ( $n=11)$ ve kandan elde edilen $(n=12)$ izolatlar daha fazla bulunmuştur. Pulsotip IX içinde yer alan 16 izolatın büyük çoğunluğu kan izolatı ( $\mathrm{n=}$ 13) olarak belirlenirken bunların büyük çoğunluğunun $(n=9)$ orta düzeyde biyofilm yapımı gösterdiği saptanmıştır. Pulsotip VI içinde yer alan 12 izolatın çoğunluğunun $(n=7)$ yine orta düzey biyofilm ürettiği ve hepsinin kan izolatı $(n=12)$ olduğu belirlenmiş̧tir.

\section{TARTIŞMA}

A.baumannii'nin idrar kateteri, santral venöz kateter, endotrakeal tüp gibi tıbbi aletlerin yüzeyinde kolonizasyonuna bağlı olarak, bakterinin abiyotik yüzeylerde üremesi sonucu 
nozokomiyal enfeksiyonlara neden olduğu bilinmektedir ${ }^{15}$. Bakterilerin biyofilm oluşturma kapasitelerinin gösterildiği çalışmalar, genellikle kateter ilişkili enfeksiyonlara neden olan izolatlar üzerinde yapılmıştır. Çalışmamızda farklı bir bakış açısıyla, ÇiD oldukları kanıtlanmış, 10 ayrı sağlık kuruluşundan elde edilerek PFGE ile klonal ilişkileri belirlenmiş invaziv A.baumannii izolatlarında biyofilm varlığı araştırılmıştır. A.baumannii'nin biyofilm yapımının araştırıldığı çalışmalarda mikrotitrasyon plak yöntemi, polistren tüp yöntemi gibi biyofilm tabakasının absorbans ölçümü temeline dayanan farklı yöntemler kullanılmaktadır. Çalışmamızda kristal viyole ile boyama yapılan mikroplak yöntemi kullanılarak biyofilm varlığı izolatların yarısından fazlasında $(\% 60.3 ; 94 / 156)$ tespit edilmiştir. Pozitif kontrol ve izolatların, üç kez tekrarlanan yöntem sonucu elde edilen OD ortalamalarına göre, ortalama biyofilm biyokütle oluşturma kapasitesinin $2.23 \pm 0.0033$ olduğu belirlenmiş ve standart izolata göre yapılan kıyaslamada invaziv izolatların standarda göre daha yüksek seviyede biyofilm oluşturdukları kanıtlanmıştır.

A.baumannii'nin biyofilm ilişkili virülans belirleyicileri olarak tanımlanan gen bölgeleri ve proteinleri; iki bileşenli sistem tarafından düzenlenen CsuA/BABCDE şaperon siste$\mathrm{mi}(\mathrm{bfmS} / \mathrm{bfmR})$, dış membran proteini olan ompA, dış membran proteini olan biyofilm ilişkili protein (bap) gibi birçok sayıda araştıııması gereken gen bölgeleridir. Son yapılan çalışmalarda, A.baumannii'nin biyofilm oluşumu üzerine etkisi olan faktörler araştırılmıştır ancak klinik izolatlardaki biyofilm oluşumuna katkı sağlayan genlerin araştırılmasıyla ilgili veriler kısıtlıdır ${ }^{16,17}$. Bu nedenle, çalışmamızda 156 adet A.baumannii klinik izolatında biyofilm oluşumuyla ilişkisini aradığımız ompA, csuE, fimH ve csgA genleri PCR yöntemiyle incelenmiştir. A.baumannii'de biyofilm varlığının antibakteriyel direnç ve dış ortamda uzun süre canlı kalabilmesinde rolü olduğu bilinmektedir. Biyofilm oluşturan bakterilerin morfolojik, metabolik ve fizyolojik olarak farklılıklar gösterdiği çeşitli araştırmalarda ortaya konmuştur. Pseudomonas türleri, Staphylococcus epidermidis, Candida türleri başta olmak üzere mikroorganizmaların biyolojik ve diğer yüzeylere tutunmasının farklı mekanizmalarla gerçekleştiği bilinmektedir. Bakterilerin yüzeylere tutunmasında hücre motilitesi, bakteriyel ekzopolisakkarit sentezi, flajella ve pililer rol oynamaktadır. A.baumannii'nin yüzeylere tutunma mekanizmaları henüz tam olarak açıklığa kavuşmamıştır ${ }^{18}$. A.baumannii'nin plastik ve cam yüzeylerde biyofilm oluşturmasında ekzopolisakkaritlerin rol aldığının gösterildiği bir araştırmada, bakterilerde flajella veya pili bulunmamasına rağmen, diğer bakteri türlerinde pili oluşumundan sorumlu olan csuC ve csuE gen lokusları ile büyük oranda benzerlik gösteren dizilimlerin varlığı ortaya konulmuştur ${ }^{18}$. A.baumannii'nin biyofilm oluşturmasında ve yapışmasında birçok gen ürününün rol aldığı gösterilmiştir. Bununla birlikte, abiyotik yüzeylerdeki biyofilm oluşumu ve konak hücresine yapışma arasında yakın bir ilişki yok gibi görünmektedir, hücre-hücre ve hücre-yüzey etkileşimi farklı klinik izolatlar tarafından değişkenlik sergilemektedir. Bu değişkenlik, farklı pili-benzeri yapılar aracılığıyla biyotik ve abiyotik yüzeylerde yapışmayı gösterebilir ${ }^{18}$. Tomaras ve arkadaşlarının yaptığı bir çalışmada ${ }^{19}$ A. baumannii ATCC 19606 izolatının, CsuA/BABCDE şaperon sistemi aracılığıyla üretilen pilusun abiyotik yüzeylere bakterinin tutunması için gerekli olduğu saptanmıştır. Çalışmada CsuA/BABCDE şaperon sisteminin bir parçası olan csuE'nin inaktive edilmesinin biyofilm olu- 
şumunun yanı sıra pili üretiminin kaldııımasına da neden olduğu sonucuna varılmıştır. Azizi ve arkadaşlarının yaptıkları çalışmada ${ }^{20}$ ise, biyofilm varlığı kanıtlanmış 65 çiD A.baumannii izolatının hepsinde ompA ve csuE genlerinin, 43 (\%66)'ünde ise bap gen varlığının olduğu saptanmıştır. Çalışmamızda biyofilm oluşumu saptanan izolatlarda ompA ve csuE gen bölgelerinin varlığı sırasıyla, \%24.5 ve \%20.2 olarak tespit edilmiştir.

Türkiye'de A.baumannii virülans faktörleriyle ilgili az sayıda yapılan çalışmada kullanılan yöntem farklılıkları nedeniyle karşılaştırma yapılması güç olmaktadır. Eraç ve arkadaşlarının ÇiD’li 65 A.baumannii izolatında virülans faktörlerini araştırdıkları çalışmada ${ }^{21}$, biyofilm oluşturma, siderofor üretimi, serum direnci, "twitching (seğirme)" ve "swarming (yayılma)" hareketleri ile efluks pompAsı varlığı fenotipik yöntemlerle araştırılmıştır. İzolatların klonal yakınlıkları, ERIC-2 primeri kullanılarak PCR ile incelenmiş ve tespit edilen tüm klonlardan temsili birer izolat alınarak, toplam 16 bakteride virülansla ilişkili özellikler araştırılmıştır. Biyofilm oluşturma kapasitesi incelenen bu izolatlardan 12'sinin güçlü biyofilm üreticisi olduğu belirlenirken, siderofor üretimi saptanmamıştır. On altı izolattan ikisinin, serumun bakterisidal etkisine dirençli, birinin orta duyarlı, 13'ünün ise duyarlı olduğu bulunmuş, bir izolatta "twitching (seyirme)", yedi izolatta ise "swarming (yayılma)" hareketi gözlenmiştir. Çalışmamızda sözkonusu çalışmadan farklı olarak izolatların klonal yakınlıkları daha önceden PFGE yöntemiyle belirlenen izolatlar kullanılmış ve virülans genleri moleküler yöntemle gösterilmiştir. Pulsotiplere göre yapılan değerlendirmede biyofilm üreten 94 izolatın yarısının üç farklı pulsotip içinde yer alması dikkat çekicidir. Biyofilm oluşturan izolatlar en sık pulsotip II \%19.1 (18/94) içinde yer almış olup bunlar Mersin, İstanbul ve Erzurum olmak üzere üç farklı merkeze ait kan $(n=11)$, bronkoalveoler lavaj $(n=4)$, plevral sıvı $(n=$ 1) ve doku ( $n=1)$ örneklerinden oluşmaktaydı. Pulsotip II içinde güçlü biyofilm üreten kan izolatları daha fazla bulunurken, pulsotip IX ve pulsotip VI içinde yer alan izolatların büyük çoğunluğunun orta düzey biyofilm üreten kan izolatı olduğu belirlenmiştir. Pulsotip VI, Ankara ve Kayseri'deki merkezlere ait izolatlar içerirken, pulsotip IX'un Ankara ve Mersin'deki merkezlere ait izolatları içerdiği görülmüştür.

Çalışmamızda, zayıf, orta ve güçlü biyofilm yapan izolatlarda virülans genlerinin dağılımı karşılaştırıldığında, çalışılan bütün genlerin güçlü ve orta pozitif biyofilm varlığı olan izolatlarda daha fazla sayıda olduğu saptanmıştır (Tablo II). Bu durum özellikle csgA ve csuE gen varlıklarının izolatlardaki biyofilm oluşumunda katkılarının olduğunu düşündürmektedir. İzolatların patojenite gen varlığına bağlı biyofilm oluşturma mekanizmaları daha ayrıntılı çalışmalarla mümkün olabilecektir.

Sonuç olarak, bu çalışmada ÇiD invaziv A.baumannii biyofilm yapan izolatlarda yüksek oranda virülans gen varlığının saptanması, bu izolatlarda virülans ile biyofilm yapımının ilişkili olabileceğini sırasıyla csgA, ompA ve csuE gen varlıklarının izolatlardaki biyofilm oluşumunda katkılarının olduğunu, fimH geninin ise biyofilm yapımıyla ilişkili olmadığını göstermiştir.

Çalışmamızda ÇiD invaziv A.baumannii izolatlarında sıklıkla güçlü biyofilm yapımının olması ve beraberinde virülans gen varlığının yarıdan fazla izolatta saptanması bakterilerde 
biyofilm yapımının antibiyotiklere dirençli hale gelmelerinde etkili olduğunu göstermektedir. Öte yandan, antibiyotiklere duyarlı noninvaziv izolatlarda A.baumannii'nin biyofilm yapımını ve virülans genlerinin varlığını tespit edecek ileri çalışmalar, bakterinin epidemik yayılımı için antibiyotiklere dirençli suşlarda biyofilm yapımına ve virülans genlerine ne derece gereksinim duyduğunu daha iyi açıklayacaktır.

\section{ÇIKAR ÇATIŞMASI}

Yazarlar bu makale ile ilgili herhangi bir çıkar çatışması bildirmemişlerdir.

\section{KAYNAKLAR}

1. Peleg AY, Seifert H, Peterson DL. Acinetobacter baumannii: emergence of a successful pathogen. Clin Microbiol Rev 2008;21(3):538-82.

2. Nemec A, Krizova L, Maixnerova M, Reijden TJ, Deschaght P, Passet V, et al. Genotypic and phenotypic characterization of the Acinetobacter calcoaceticus-Acinetobacter baumannii complex with the proposal of Acinetobacter pittii sp. nov. (formerly Acinetobacter genomic species 3) and Acinetobacter nosocomialis sp. nov. (formerly Acinetobacter genomic species 13TU). Res Microbiol 2011;162(4):393-404.

3. Bardbari AM, Arabestani MR, Karami M, Keramat F, Alikhani MY, Bagheri KP. Correlation between ability of biofilm formation with their responsible genes and MDR patterns in clinical and environmental Acinetobacter baumannii isolates. Microb Pathog 2017;108:122-8.

4. Metan G, Sariguzel F, Sumerkan B. Factors influencing survival in patients with multi-drug-resistant Acinetobacter bacteraemia. Eur J Intern Med 2009;20(5):540-4.

5. Zarrilli R, Giannouli M, Tomasone F, Triassi M, Tsakris A. Carbapenem resistance in Acinetobacter baumannii: the molecular epidemic features of an emerging problem in health care facilities. J Infect Dev Ctries 2009;3(5):335-41.

6. Wright MS, Jacobs MR, Bonomo RA, Adams MD. Transcriptome remodelling of Acinetobacter baumannii during infection and treatment. MBio 2017;8(2):e02193-16.

7. Mohajeri P, Rezaei Z, Sharbati S, Rasi H, Rostami Z, Farahani A, et al. Frequency of adhesive virulence factors in carbapenemase producing Acinetobacter baumannii isolated from clinical samples in west of Iran. Asian J Biol Sci 2014;7(4):158-64.

8. Boral B, Unaldi Ö, Ergin A, Durmaz R, Eser ÖK; Acinetobacter Study Group. A prospective multicenter study on the evaluation of antimicrobial resistance and molecular epidemiology of multidrug-resistant Acinetobacter baumannii infections in intensive care units with clinical and environmental features. Ann Clin Microbiol Antimicrob 2019;18(1):19.

9. Badave GK, Dhananjay K. Biofilm producing multidrug resistant Acinetobacter baumannii: An emerging challenge. J Clin Diagn Res. 2015; 9(1):DC08-DC10.

10. Braun G, Vidotto MC. Evaluation of adherence, hemagglutination, and presence of genes codifying for virulence factors of Acinetobacter baumannii causing urinary tract infection. Mem Inst Oswaldo Cruz 2004;99(8):839-44.

11. Turton JF, Gabriel SN, Valderrey C, Kaufmann ME, Pitt TL. Use of sequence-based typing and multiplex PCR to identify clonal lineages of outbreak strains of Acinetobacter baumannii. Clin Microbiol Infect 2007;13(8):80715.

12. Lewis K. Riddle of biofilm resistance. Antimicrob Agents Chemother 2001;45(4):999-1007.

13. Rodríguez-Baño J, Martí S, Soto S, Fernandez-Cuenca F, Cisneron JM, Pachon J, et al. Biofilm formation in Acinetobacter baumannii: associated features and clinical implications. Clin Microbiol Infect 2008;14(3):2768.

14. Weldhagen GF, Poirel L, Nordmann P. Ambler class A extended-spectrum beta-lactamases in Pseudomonas aeruginosa: novel developments and clinical impact. Antimicrob Agents Chemother 2003;47(8):2385-92. 
15. Longo F, Verotto C, Donelli G. Biofilm formation in Acinetobacter baumannii. New Microbiol 2014;37:11927.

16. Wright MS, lovleva A, Jacobs MR, Bonomo RA, Adams MD. Genome dynamics of multidrug-resistant Acinetobacter baumannii during infection and treatment. Genome Med 2016;8(1):26.

17. Eze EC, Chenia HY, El Zowalaty ME. Acinetobacter baumannii biofilms: effects of physicochemical factors, virulence, antibiotic resistance determinants, gene regulation, and future antimicrobial treatments. Infect Drug Resist 2018;11:2277-99.

18. Liu H, Wu YQ, Chen LP, Gao X, Huang HN, Qiu FL, et al. Biofilm-related genes: Analyses in multi-antibiotic resistant Acinetobacter baumannii isolates from mainland China. Med Sci Monit 2016; 22:1801-7.

19. Tomaras AP, Dorsey CW, Edelmann RE, Actis LA. Attachment to and biofilm formation on abiotic surfaces by Acinetobacter baumannii: Involvement of a novel chaperone-usher pili assembly system. Microbiology 2003;149(Pt 12):3473-84.

20. Azizi O, Shahcheraghi F, Salimizand H, Modarresi F, Shakibaie MR, Mansouri SH, et al. Molecular analysis and expression of bap gene in biofilm-forming multi-drug resistant Acinetobacter baumannii. Rep Biochem Mol Biol 2016;5(1):62-72.

21. Eraç B, Yılmaz FF, Hoşgör Limoncu M, Öztürk I, Aydemir Ş. Çok ilaca dirençli Acinetobacter baumannii izolatlarında virülans faktörlerinin araştırılması. Mikrobiyol Bul 2014;48(1):70-81. 